\title{
Business Career of Russian Banking Organizations' Employees: Priorities and Opportunities
}

\author{
Nikita Z. Sotnikov, Svetlana I. Sotnikova \\ and Elena M. Mikhailova* \\ Novosibirsk State University of Economics and Management \\ Novosibirsk, Russian Federation
}

Received 05.03.2019, received in revised form 02.12.2019, accepted 12.12.2019

\begin{abstract}
Such traditional methods of labour efficiency maximization as rationalization, automation of business processes, and head hunting, do not often yield better competitiveness of human resources in the context of modern "transparent" world market development and high uncertainty and dynamism of Russian socioeconomic environment. It is necessary to create proper conditions for the employees to continuously and consciously work towards long-term superiority over competing employees and to increase their professional competences in order to be competitive in the labour market. The objective of this research is to identify the organizational and economic patterns of business career created by differences in the competitive position of banking organizations. The study encompassed the analysis of business careers of the employees of fifteen federal and regional banks quoted in the Russian market during the past six years. The results of the research prove that the type and intensity of business career determine the mechanisms for localization and establishment of the competitive advantages of both the employee and the bank in the market situation. The business career studies made it possible to identify the presence of a socioeconomic conflict between professional and organizational (intraand inter-organizational) career. The business career conflict solutions generate strategic alternatives for the integrating the professional and organizational types of career, in order to maintain and increase the competitiveness of human resources of the banking organization.
\end{abstract}

Keywords: banking organization, staff competitiveness, business career.

Research area: economics.

Citation: Sotnikov, N.Z., Sotnikova, S.I., Mikhailova, E.M. (2020). Business career of Russian banking organizations' employees: priorities and opportunities. J. Sib. Fed. Univ. Humanit. Soc. Sci., 13(7), 1182-1194. DOI: 10.17516/1997-1370-0530.

\footnotetext{
(C) Siberian Federal University. All rights reserved

* Corresponding author E-mail address:n.z.sotnikov@edu.nsuem.ru, s.i.sotnikova@nsuem.ru, e.m.mihajlova@nsuem.ru ORCID: 0000-0002-6406-8683 (Sotnikov); 0000-0003-1723-9387 (Sotnikova); 0000-0002-4597-754X (Mikhailova)
} 


\section{Introduction}

For many years, business career has been in the focus of studies carried out by Soviet, Russian and foreign researchers. The interest to the process, its scale, intensity and factors is not a coincidence: it clearly manifests many important and regular processes of social mobility of the work force, and reflects the dynamism of the labour market.

In scholarly literature, business career is presented as a complex, open and holistic system, illustrating the highest degree of unity of three interrelated substances.

First, business career becomes a factor in achieving personal success and outperforming other competing employees who are pursuing identical goals (Sotnikov, 2015; Hassell, 2017; Masie, 2017; etc.). The result of personal success and outperforming the competitors in the social life stream is maintenance and improvement of the working life quality, achieved by the employee. It is associated "with an increase of wages, the level of official rights and duties, the degree of autonomy and responsibility" (Miliaeva, 2016).

Secondly, business career appears as a function of social mobility (Eriomina \& Toderash, 2016; Sillaste, 2004; Hall \& Mirvis, 1995; Savickas, 1992).

Social mobility manifests itself as "a systemic phenomenon that reflects the objective side of an individual's socialization process (the content and directions of socioeconomic, educational, cultural policies, as well as functions, principles, objectives in the management of society, legislative, regulatory, organizational, behavioural and other conditions of social being) and subjective (the complex of basic personal qualities that also determine the content and direction of social mobility)" (Shpektorenko, 2013).

Thirdly, business career is presented as an activity of positioning an employee in the hierarchical stratified labour division system (Beliatskiy, 2010; London \& Moon, 1987; Noe et al., 1990; Bersin, 2015; Schein, 1986; Sotnikova, 2018, etc.). To our best knowledge, positioning of an employee in the labour market can be personal-professional, representing the localization (fixation) and consolidation of a certain status (position) and role of the employee in the professional field of activity, with regard to his/her knowledge, skills and attitudes. It can also be status-official, finding the social and material achievements in specific non-organizational and intra-organizational realities, perceived as an objective status set and clearly defined positions, roles, states of financial well-being, etc.

Thus, the modern business career concept is associated with awareness of the fact that freedom of career generates competition, creating obstacles for everyone on the way to achieving personal success and outstripping competitor employees, working towards the same goals. The elevation of one's professional life quality is the result of achieving personal success and surpassing competitors in social life. Business career becomes a priority (leading) factor in the competitiveness of human resources in the labour market.

\section{Problem Statement}

The re-industrialization vector in Russian economy is associated with a shift of the banking sector development paradigm. Such changes imply improving quality of banking assets against the intention to expand the banking business through aggressive marketing technologies, product concept against customer-oriented ideology. The most important economic challenge in creation of competitive commercial bank personnel is caused by fundamental transformation of values, worldview and ideological settings all over the world. It is impossible to improve the quality of assets, to reduce the share of dubious operations in troubled banks in a short term, to prevent a full-scale crisis of confidence against the background of the unstable economic situation without professionally trained and loyal staff.

In this context, business career represents a process of competitive positioning of an employee in the labour division market system. It contributes to the preservation or improvement of the working life quality due to labour mobility in the changing conditions of intra-organizational and non-organizational realities.

In essence, business career (Fig. 1): 


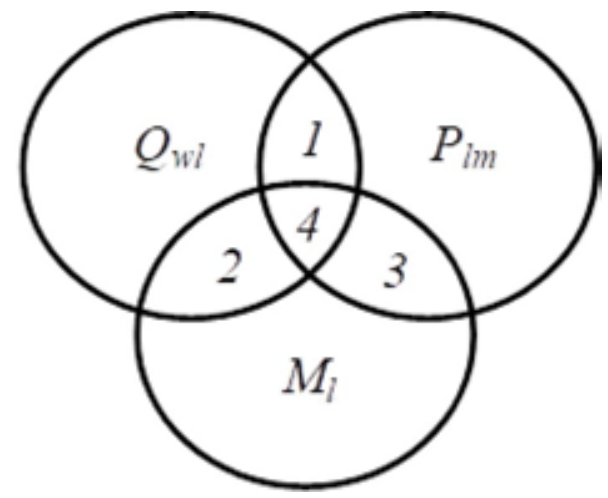

Fig. 1. Modern triad system of business career: Qwl - quality of working life, $\mathrm{Ml}$ - labour mobility, Plm - labour market positioning

a) models the system of principles for achieving the desired quality of working life in the context of labour mobility;

b) specifies the conditions and forms of labour mobility, which allows to support or improve one's competitive position in the labour market;

c) determines the parameters of competitive positioning in the labour market that contribute to the improvement of the quality of working life.

Constant changes in legislation, unstable market conditions, severe competition, rapidly developing preferences of employers expand the range of business career strategies that combine different options for employee relocation, depending on the ratio of the three substances of business career. The simplified stereometric business career model (Fig. 1) clearly demonstrates the variability of strategies, including increasing (in sectors 1, 2, 3, 4) and preserving (in sectors Qwl, Ml, Plm) the competitiveness of the employee.

Sector 1 is the combination of such two business career substances as quality of working life and labour market positioning. This business career dyad determines the strategy of a contender for market leadership. Such situation is typical for employees, seeking to improve the quality of their working life through reinforcement of their competitive position in the labour market, based on the actual conditions of socioeconomic development of the households, organizations, regions, etc.
Sector 2 is the combination of quality of working life and labour mobility substances. This dyad defines the professional niche strategy. It characterizes the career of those employees, who manage to improve the quality of their working life in a particular segment of the labour market through the development and usage of their professional skills, awareness of the importance of their professional competence and confidence in it, high motivation in achieving results in one way or another.

Sector 3 is the intersection of labour mobility and labour market positioning substances. This business career dyad determines the strategy of a market follower. The career of the employees, who form this segment, is characterized by the necessity for creative involvement in management and production, in searching for development potential, not only by increasing qualification requirements, but also through discipline. For these employees, the priority belongs to functional flexibility, focus on expansion and enrichment of the job, reinforcement of creative aspects.

Sector 4 is a combination of all three substances of the business career triad, namely, quality of working life, labour mobility, labour market positioning. This segment unites the careers of those employees, who harmoniously and totally achieve the personal-professional and status-official positioning in the labour market, thereby ensuring business success. This segment is distinguished with competitive leadership strategy. 
Qwl Sector is the quality of working life sector. This substance means avoiding direct competition strategy. This is a strategy of focusing one's career on maintaining the achieved quality of working life, certain pliability to the stricter requirements of the employer in order to preserve the job and all existing and future benefits associated with it.

Ml Sector is the labour mobility segment. It implies implementation of rotation strategy of a specialist being a professional in his or her field, but easy enough to being training for another job within his or her organization. The career of such employees is focused on diversification of knowledge, skills, abilities, enabling them to adapt to the changes in working technique and technology, as well as culture of behaviour. These employees are flexible in reacting to production and market changes or demand fluctuations.

Plm Sector is the labour market positioning segment. It features a peripheral professional strategy. It is normally implemented by the employees who have the proper professional, but not organization-specific skills. It unites the careers of those employees, who aim to preserve the sovereignty of their social status and role, a certain autonomy and independence in the professional life.

Thus, career is a dialectical system. Emergence, formation and resolution of inherent contradictions between the three substances (quality of working life, labour mobility and labour market positioning), which allow the employee to have sustainable competitive advantages in the labour market, create the driving force and resource for business career development.

In this context, there is a growing need for understanding the general nature and underlying causes of the business career commencement, development and destruction processes, with due regard to the competitive position of a banking organization and its strategy transforming capacity. Theoretical and methodical comprehension of a business career model as a metamodel of bank personnel competitiveness will make it possible to understand the parameters, conditions and characteristics of a business career strategy capable of forming a strategic potential for the banking labour market.

\section{Research Questions}

Despite a significant contribution currently made to the development of certain aspects of the investigated problem and, particularly, the sociopsychological ones, there is a shortage of conceptual studies of business career as a socioeconomic mechanism for the banking personnel competitiveness development. In this context, the present article covers the following questions:

- In what types of business career and to what extent can they achieve a higher level of banking personnel competition in the labour market in the changing environment?

- What are the possible strategic alternatives for maintaining a competitive position in the labour market, given the development strategy of the banking organization?

\section{Purpose of the Study}

The objective of the research is to develop an organizational and economic foundation for banking personnel career as a mechanism for improving competitive positions in the labour market: (a) to identify the determinants of business career, allowing to achieve a higher level of competition in the labour market in the changing conditions; (b) to analyse various strategic alternatives of business career by building two-dimensional matrixes, estimating the prospects of a particular method of bank personnel positioning in the labour market. The organizational and economic regularities revealed in the business career studies and conditioned by the differences in the competitive position of banking organizations, allow us to identify and forecast the favourable opportunities and threats that may arise on the way to gaining competitive advantages in the labour market.

\section{Research methods \\ Hypothesis development \\ Correlation between business career and employee competitiveness}

A business career predefines one's individual conscious way of forming a competitive po- 
sition in the labour market in order to achieve the desired quality of working life. In its turn, competitiveness as such is the basis of a career, in which new positions in the labour division are developed. Therefore, it determines the opportunities and conditions for the development and satisfaction of the physical, spiritual and social needs of an employee.

H1: Business career is an employee competitive development mechanism based on the principle of changing one's competitive position in the labour market in order to cater their need for a better quality of working life.

\section{Duality of business career}

Duality of business career is a philosophical comprehension of the harmony between two types of the argumentation of competitive positioning in the labour market: subjectively irrational and objectively rational. On one hand, the dual approach to business career analysis allows considering it as a subjectively irrational career activity, associated with identification and satisfaction of the employee's needs for competitiveness and wellbeing throughout their working life. On the other hand, such approach describes business career as limited and objectively defined by the existing rules and status-role prescriptions, existing in the stratified labour division system of the market, i.e. considered as an objectively rational career activity.

$\mathrm{H} 2$ : The dynamics of objectively rational activity and the dynamics of subjectively irrational activity obey to the different laws. Therefore, they do not coincide in time and change trends. As a result, there occurs an economic and organizational conflict between professional and organizational careers, including the conflict between intra-organizational and inter-organizational careers.

\section{Targeted business career}

Career is always targeted. The goal of a career should be considered from two perspectives, two subjects: the employer and the employee. The basis for a common career target is the establishment of proper conditions for the coordination of individual and organizational goals.
H3: Business career depends on the way an employee is positioned in the labour market, but not so much on the organizational needs of the labour force. This way, it is determined by the employee's intrinsic need for improving the quality of work life, desire for self-expression in the outside world and among other competing employees, who are pursuing the same goals.

\section{Data collection procedure}

The statistical data of all-Russian statistical reporting, analytical reviews, and primary personnel documents of commercial banks, banking sector regulations, press information, the Internet data, along with the results of the author's survey of bank employees served as the information and empirical base for the research.

Fifteen federal and regional Russian banks were observed.

The study consisted of several levels.

The first level implied specification of the indicators to be used to assess objectively rational career activity. Thus, on this level, the career system was studied as a holistic complex of resources used to achieve a higher level in the competition of bank personnel in the labour market (Fig. 2). The main method of the research was statistical data analysis. The study was conducted by quota multistage sampling (basic characteristics: location of the organization, corporate strategy, bank personnel headcount).

It is noted that over the years 2010-2018, increase in the career activity of bank employees was observed as national economy stabilized after the 2008 recession. At the same time, the dynamics of activity strongly depends on the development strategy of the banking organization: entrepreneurial strategy provides the greatest opportunities for a business, cyclical strategy and profitability strategy provide the least potential, while dynamic strategy of growth and liquidation strategy offer moderate opportunities (Fig. 2).

The second level of the research was based on the first level. On the second level, the subjectively irrational career activity was specified, as personal expectations of the employee, 


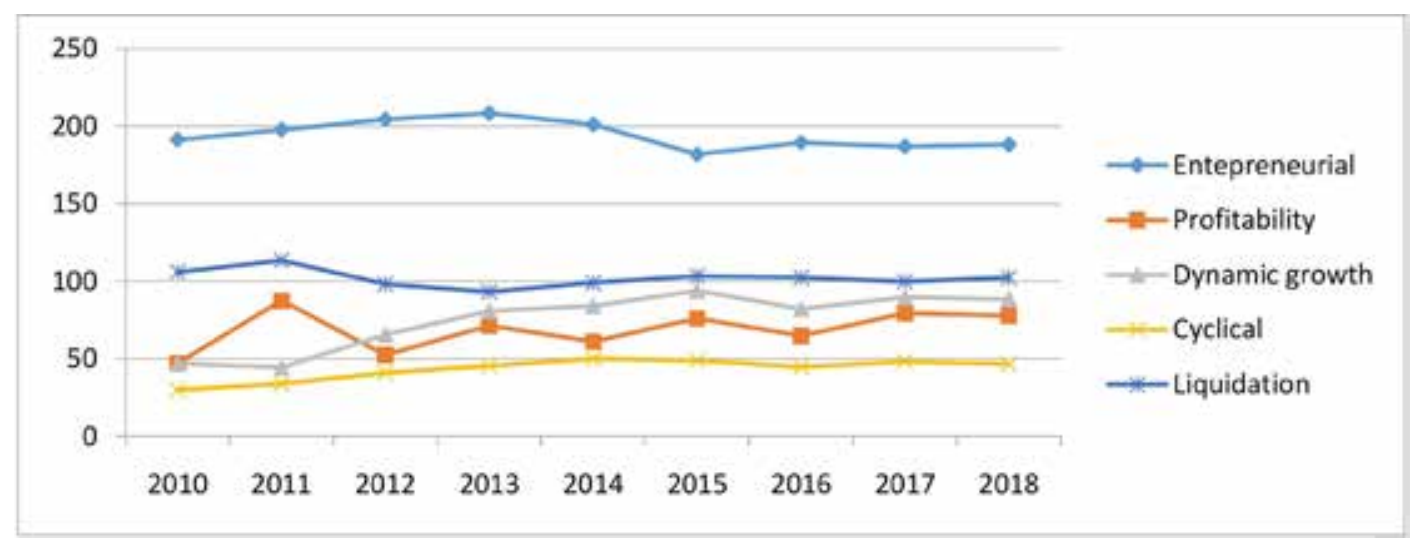

Fig. 2. Business career intensity depending on the strategy of the banking organization over the period $2010-2018, \%$

Table 1. Distribution of answers to the question "What does the term of "business career' mean to you?"

\begin{tabular}{|l|c|}
\hline \multicolumn{1}{|c|}{ Business career is ... } & Answers (\%) \\
\hline achieving decent and increasing material wellbeing for myself and my loved ones & 67.8 \\
\hline $\begin{array}{l}\text { having comfortable working conditions (working in a clean healthy environment, having a } \\
\text { personal office, personal car, etc.) }\end{array}$ & 40.5 \\
\hline development of good personal relations with managers, colleagues, subordinates & 44.7 \\
\hline respect and prominence in the organization & 53.4 \\
\hline professional competence development & 57.8 \\
\hline achieving success and prominent position in society and in the professional world & 68.3 \\
\hline achieving superiority over other people & 70.1 \\
\hline non-standard, creative, innovation work & 45.4 \\
\hline employee development, that does not conflict with his/her lifestyle & 43.2 \\
\hline activity of unleashing one's labour potential & 55.6 \\
\hline recognition of professional achievements & 52.1 \\
\hline guarantee of a constant job, stable position & 44.6 \\
\hline
\end{tabular}

regarding material well-being, self-affirmation, self-esteem, public recognition, economic independence, success, power, etc. These expectations were associated with self-assessment not only in the context of needs and motivation of the employee, but also in the socioeconomic, organizational conditions of self-positioning in life and work.

The questionnaire survey was the main research method used on this level (Table 1). The study was conducted by quota multistage sampling (basic features: corporate strategy, functional responsibilities of the employee and work experience of the employee at the banking organization).

During the research, it was noticed that for most bank employees, career is a process of official professional positioning in the reality of their organization: achieving superiority over other people $(70.1 \%)$, a way to success and a prominent position in society and in the professional world (68.3\%), recognition of professional achievements (52.1\%).

It is also rather typical for bank employees to perceive career as a personal-professional positioning in the environment of their 
Nikita Z. Sotnikov, Svetlana I. Sotnikova... Business Career of Russian Banking Organizations' Employees...

Table 2. Differences in understanding the meaning of business career among employees of banking organizations with different development strategies (based on the survey results), in per cent of the total number of respondents

\begin{tabular}{|c|c|c|c|}
\hline \multirow{2}{*}{ Type of strategy } & \multicolumn{3}{|c|}{ Business career is } \\
\cline { 2 - 4 } & a job-official positioning & $\begin{array}{c}\text { a personal-professional } \\
\text { positioning }\end{array}$ & $\begin{array}{c}\text { a way to cater one's } \\
\text { material needs }\end{array}$ \\
\hline Entrepreneurial & 18 & 61 & 21 \\
\hline Profitability & 28 & 25 & 47 \\
\hline Dynamic growth & 67 & 22 & 11 \\
\hline Cyclical & 24 & 54 & 22 \\
\hline Liquidation & 25 & 23 & 52 \\
\hline
\end{tabular}

organization: professional competence development $(57.8 \%)$, which does not conflict with the lifestyle (43.2\%) in order to carry out their professional tasks in a non-standard, creative, innovative way $(45.4 \%)$, unleash their labour potential $(55.6 \%)$ and increase their value and reputation in the organization (53.4\%).

Career is often regarded as a way to cater material needs, such as material well-being $(67.8 \%)$, better working conditions $(40.5 \%)$, good personal relations in the team $(44.7 \%)$, guarantees of a permanent job and stable position (44.6\%).

It is not difficult to notice that business career is associated with achieving some personal success in the form of more or less clearly defined positions, statuses, roles, perceived as a result of maintaining or improving the quality of working life by getting a sense of superiority over other employees. At the same time, there are differences in understanding the meaning of business career among employees, depending on the corporate strategy (Table 2).

Thus, in banks practicing the dynamic growth strategy, employees normally consider career in the context of job-official positioning (67\%). For these employees, career appears as a series of promotions from one job (position) to another, development of their influence, power, authority, status in the company. Career growth, functional expansion in the organization is harmonized and accelerated by means of training in the use of new technologies, requalification and career orientation.

Career means mastering a variety of skills and competences that complement and develop a professional for the employees of the banks, implementing the entrepreneurial $(61 \%)$ and cyclical (54\%) strategies. For them, their career path is directly related to personal-professional positioning. Often, such employees are "focused" on the training aspect of career and make the typical mistake, considering training as a target, not as a tool for improving their intra-organizational positioning and advancement of their competitiveness.

Employees in banks with the profitability $(47 \%)$ and liquidation strategies $(52 \%)$ often perceive their careers as a way to protect their own status and income, associated with their activity in the organization. These employees are quite loyal to the organization. Their main problem is the threat of the so-called "career plateau" or "career downshifting" the situation when employees professionally "outgrow" their official positions.

\section{Findings}

\section{Economic expediency of the business career of employees}

Business career is the highest criterion of qualification assessment and self-motivation to achieve sustainable (organizational or personal) competitive superiority over other employees with the least career investment: $T C \rightarrow \min$. Career investment is a long-term investment of capital into the positioning of an employee in order to preserve or overcome (elevate) the achieved quality of working life.

Economic expediency of an employee's career is determined by comparing the values of marginal income MR and marginal invest- 


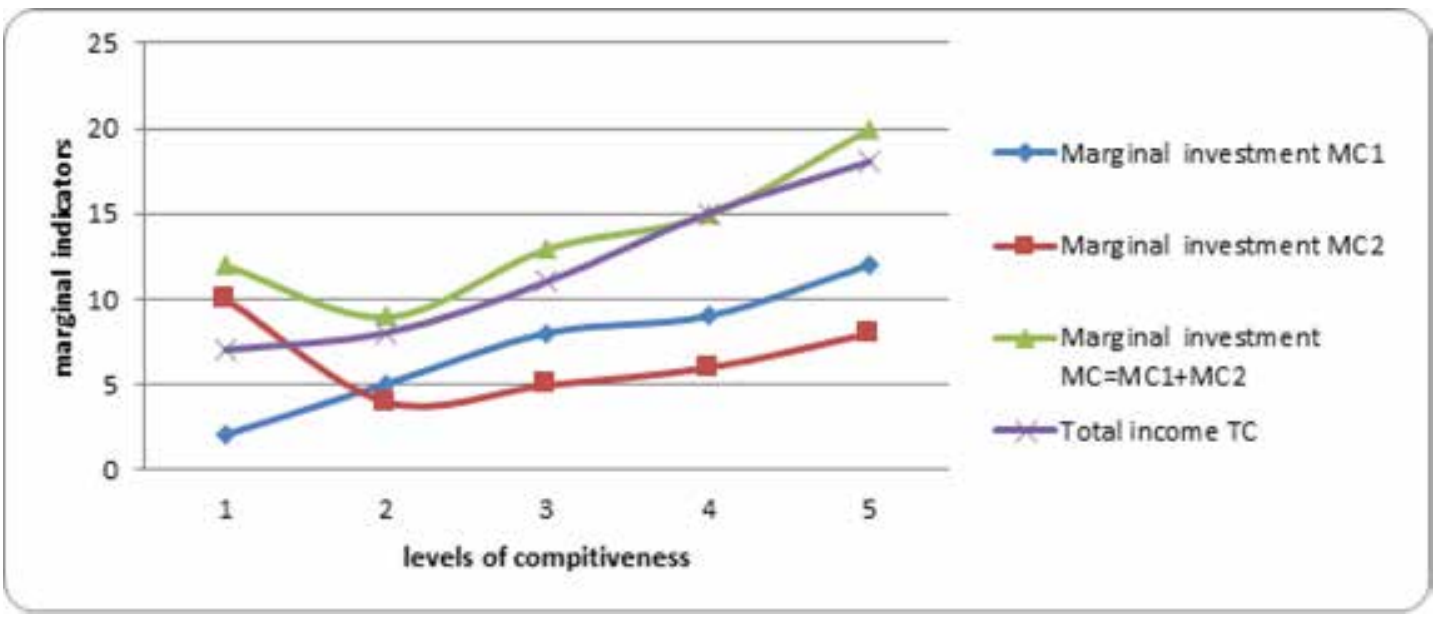

Fig. 3. Dynamics of marginal income and marginal investment in a career, depending on the level of employee competitiveness

(using the example of a bank with entrepreneurial strategy), thousand RUR

ment $\mathrm{MC}$, associated with the dynamics of the quality of working life, determined by the competitiveness of the employee (including investment in personal $\mathrm{MC} 1$ and corporate $\mathrm{MC} 2$ types of competitiveness) (Fig. 3).

As can be seen from Fig. 3, employees seek to acquire a certain share of the domestic labour market and secure it for themselves in the situation $M R \prec M C$. The employee is focused on reimbursement of costs, associated with the achievement of a career position in the labour market as any owner of economic resources.

The employee seeks to get a target profit from his/her positioning in the situation $M R \succ M C$. But in this case, the employee enjoys personally significant benefits from better competitive advantages, yielding the growth of their total income and improvement in the quality of working life. At the same time, an additional increase in one's competitiveness reduces the growth rate of their marginal income according to the law of diminishing returns.

The employee gets his/her income from the career in accordance with his/her competitiveness, when $M R=M C$. This is when the formula "from each according to his ability, to each according to labour" finds its real meaning.

The employee considers investing in a professional career as a way to improve his/her status-official positioning in the labour market, when $M C_{1}=M C_{2}$.

The employee is focused more on positioning his/her influence, power, authority, status in the professional environment in a specific inter-organizational and intra-organizational reality, when $M C_{2} \succ M C_{l}$.

\section{Economic-organizational compromise between professional and organizational, inter-organizational and intra-organizational careers}

During the research carried out in banking organizations, business career was found to be perceived as a way to achieve competitiveness in the labour market. Among the mechanisms involved in this process, there is, first of all, the professional career mechanism, which creates conditions for professional development and implies continuous reproduction of competitive advantages throughout the working life of each employee. The second mechanism deployed is intra-organizational career, associated with the professional and official positioning of the competitive advantages of the employee in a stratified labour division system, with due regard to the inter-organizational and intra-organizational realities. Thirdly, the inter-organizational career mechanism is used, focused on 
the transition of an employee from one organization (branch) to another in order to change the professional or official position, and the level of competitiveness of the organization itself or its territorial location.

At the same time, the processes of formation, development and destruction of professional and organizational (intra-organizational and inter-organizational) careers are regulated by different laws, namely, internal unity and interpenetration. The mismatch between their timing and change trends generates an economic and organizational conflict between them (Table 3), which contributes to changes in the competitive position of employees and banking organizations in the labour market. In the perfect scenario, this conflict shall be resolved in order to protect the intellectual capital of a banking organization from stagnation in business activities, and to identify new development opportunities.

The dynamic growth strategy is applied to achieve the dialectic coordination of opportunities for professional and intra-organizational career. The employee gets a unique opportunity to unleash his/her potential and to enrich his/ her experience and thereby to speed up their further promotion. The employer organization minimizes their risks by hiring responsible and successful people, respecting the corporate culture, to get predictable results from the career of such employees

In the context of the cyclical corporate development strategy, it is professional career that is in the focus of attention. Such strategy allows the employer to improve the skills of the loyal employees, to diversify their competencies by accumulating and using their new competitive advantages, to maximize their contribution to the organizational development of the bank and to adapt to the changing environment with the lowest economic and social costs due to the multi-functionality of manpower at hand. In turn, there is a real opportunity for employees to improve their competitive position in the labour market, to expand their prospects for promotion and to increase incomes from employment, mastering the new market segment of employers.

Compromise between inter-organizational and intra-organizational careers in entrepreneurial and liquidation strategies for the development of banking organizations, as well as profitability strategy, is possible when sustainable competitive advantage in the labour market is being achieved by stimulating employees with a frequent rotation from one organization or one level of the company to another, retaining their official position.

In the organizations practicing the cyclical development strategy, the compromise is being achieved to guarantee further operation of the employer in business management, to ensure their safety by means of filling the key positions with loyal and proven people, who know the specifics of business and organization, and encouraging them to professional self-development.

Table 3. Business career strategy depending on its intensity: "strategy - career" matrix, coefficient

\begin{tabular}{|l|c|c|c|c|c|}
\hline \multirow{2}{*}{ Type of strategy } & \multicolumn{5}{|c|}{ Intensity of business career $s=\left(s^{\text {out }} ; s^{\text {in }} ; s^{p}\right)$} \\
\cline { 2 - 6 } & $\begin{array}{c}\text { dominant } \\
\left(1<s^{p}<s^{o}\right)\end{array}$ & $\begin{array}{c}\text { high } \\
\left(s^{p}<s^{o} \leq 1\right)\end{array}$ & $\begin{array}{c}\text { natural } \\
\left(s^{o}=s^{p}\right)\end{array}$ & $\begin{array}{c}\text { favourable } \\
\left(s^{o}<s^{p} \leq 1\right)\end{array}$ & $\begin{array}{c}\text { favourable } \\
\left(1<s^{o}<s^{p}\right)\end{array}$ \\
\hline Entrepreneurial & & & & & $(1,99 ; 0,04 ; 2,62)$ \\
\hline Dynamic growth & & & & & $(0,2 ; 0,69 ; 1,21)$ \\
\hline Profitability & & & $(0,58 ; 0,23,0,83)$ & & \\
\hline Liquidation & $(1,02 ; 0,34 ; 0,68)$ & & & $(0,43 ; 0,42 ; 1,0)$ & \\
\hline Cyclical & & & & & \\
\hline
\end{tabular}

Note: $s$ - intensity of business career; $\mathrm{s}^{0}=\left(\mathrm{s}^{\mathrm{out}}+\mathrm{s}^{\mathrm{in}}\right)$ - intensity of corporate career; $\mathrm{s}^{\text {out }}$ - intensity of inter-organizational career; $\mathrm{s}^{\mathrm{in}}$ - intensity of intra-organizational career; $\mathrm{s}^{p}-$ intensity of professional career.

$\checkmark$ Natural business career.

Intensive business career.

Extensive business career. 
With the dynamic growth strategy, the subjects of the domestic banking labour market form a competitive space, which naturally brings business career to the state of self-development and self-regulation, contributing, according to the competition laws, to the fullest satisfaction of the diverse interests of the economic actors in improving their working life quality.

Thus, business career operates like a dialectical system. Its driving force and source of development are the processes of emergence, formation and resolution of the intrinsic conflict between professional and organizational, inter-organizational and intra-organizational careers.

\section{Social expediency of the business career of employees}

The indicator of the career's social expediency is success. It is subjective assessment of the conditions and results of the achieved personally significant benefits from self-positioning in the organizational labour division system.

Career success is a relative concept. It reflects individual assessment of work success (determined by the dynamics of personally significant achievements in the career comparative to different time periods of working life) and social success (determined comparative to the achievements of other employees, seeking the same career goals). In fact, it is functionally dependent on the effectiveness and career satisfaction (Table 4).

Commonly, employees understand assessment of career satisfaction as a degree of satisfaction of their needs. For that purpose, they realize to what extent the conditions provided by a particular position in the organization allow them to improve the quality of their working life by satisfying their needs for recognition, development, self-fulfilment, dominance over other employees, power, material well-being, and independence.

In this context, career efficiency is its economic value, determined by comparing personally significant benefits from the career to the cost of achieving them, i.e. comparing the need for a career with the capacity of getting it. The employees normally assess career efficiency through the prism of the personally significant needs for development, recognition, perfection, providing the opportunity to improve the quality of life, and the market opportunities to meet such needs. This assessment sets the employees' career preferences based on the principle of "easy/difficult", "achievable/unachievable", "acceptable/unacceptable", etc.

A career is recognized as successful if it enables the employee to achieve a competitive position in the labour market, and if this position is achieved in the most rational way, namely, at minimal socioeconomic costs.

Thus, business career depends rather on the way an employee is positioned in the la-

Table 4. Classification of business career models depending on success $S_{c k}=f\left(S_{c}, E_{c}\right)$, coefficient

\begin{tabular}{|c|l|l|}
\hline \multirow{2}{*}{ Career satisfaction $\left(S_{c}\right)$} & \multicolumn{2}{|c|}{ Career effectiveness $\left(E_{c}\right)$} \\
\cline { 2 - 3 } & \multicolumn{1}{|c|}{ low high } \\
\hline high & $\begin{array}{l}\text { Banks with } \\
\text { Profitability }(52 ; 33) \text { and Cyclical }(58 ; 34) \\
\text { strategies }\end{array}$ & $\begin{array}{l}\text { Banks with Dynamic growth strategy } \\
(54 ; 61)\end{array}$ \\
& $\begin{array}{l}\text { Segment D } \\
\text { Humanistic model }\end{array}$ & $\begin{array}{l}\text { Segment A } \\
\text { Marketing model }\end{array}$ \\
\hline low & $\begin{array}{l}\text { Banks with Entrepreneurial strategy (35; } \\
\text { 30) }\end{array}$ & $\begin{array}{l}\text { Banks with Liquidation strategy } \\
\text { (41; 53) }\end{array}$ \\
& $\begin{array}{l}\text { Segment C } \\
\text { Adaptive career model }\end{array}$ & $\begin{array}{l}\text { Segment B } \\
\text { Technocratic career model }\end{array}$ \\
\hline
\end{tabular}

Note: $S_{c k}$ - career success; $S_{c}$ - career satisfaction; $E_{c}$ - career effectiveness. 
bour market, due to his/her intrinsic need for better quality of working life, the desire for self-expression in the surrounding world and overcoming other employees seeking the same goals, than the right to work guaranteed by the state.

\section{Conclusion}

Business career is a dialectic system, driven by the processes of emergence, development and resolution of the intrinsic contradictions (conflicts) between professional and organizational (intra-organizational and inter-organizational) careers. These contradictions are resolved with the purpose of maintaining or improving the competitive position of the bank in the labour market. In this context, four strategic alternatives should be distinguished, depending on the organizational development strategy of the bank: A - marketing, B - technocratic, $\mathrm{C}$ - adaptive, D - humanistic (Table 4).

The marketing strategic alternative business career (A) is typical for banks with a dynamic growth strategy. It focuses on the dialectical coordination of opportunities for professional and organizational careers. The employee gets a unique opportunity to unleash his/her potential and enrich his/her experience, thereby promoting their promotion. The employer organization minimizes their risks by appointing proper specialists to the vacant positions. Rationally connected with the business strategy, career is built with great regard to the objective criteria for assessing professionalism, education background, creativity and communication skills of the employee.

The technocratic strategic alternative business career (B) is typical for banks adhering to the liquidation development strategy. It looks up to the interests of the employer, stimulating the employee to work for a social and professional status for the sake of the status itself, or the process of movement in the organizational system of division of labour for the sake of the process itself. The goal is presented either as a certain position within the company or an activity to be carried out by the one occupying the position. Such focus creates a fierce competition for more favourable conditions of professional activity. In this model, career is made not only by the professional experience and activity of the employee, but also through protectionism.

The adaptive strategic alternative business career (C) is typical for banks practicing the entrepreneurial strategy. It allows the banks to react to the processes occurring in the outer world, finding a compromise between the personal-professional and the status-official positioning of the employees to meet the consumer demand for labour. It implies creation of the conditions for employees to master related professions, including the duties performed by the colleagues superior or inferior in the corporate hierarchy, and, consequently, allows for mechanical movement of employees from one workplace to another inside and outside the organization, depending on the changing workload requirements.

The humanistic strategic alternative business career (D) is popular in the banks, deploying the profitability or cyclical strategies. The humanistic focus is expressed in the consideration of the social and professional environment in terms of benefits, especially for employees, which is manifested in meeting their personal needs (including healthcare and financial stability) through self-improvement, training in new technologies, requalification, new experience in professional trainings and geographic mobility, change of social circle, lifestyle in general. The interests of individual employees prevail over the interests of the organization.

Based on the above, business career, which in the modern conditions acquires a new socioeconomic meaning, appears to be a mechanism for interaction between the professional and organizational (intra-organizational and inter-organizational) careers, contributing to the improvement of one's competitive position in the labour market for catering their needs for better working life. The knowledge of strategic alternatives of business career can be used to make a comprehensive impact on the competitive advantages of employees, to identify specific functions and regulatory capabilities of each type of positioning to improve the employees' competitive positions, to find the connections 
between other professional phenomena and processes, to monitor the dynamics of the relations between the quality of working life and competitiveness of each individual employee, the personnel of the organization and entire economically active population in general.

\section{References}

Beliatskiy, N.P. (2010). Metodicheskoe obespechenie kar'ernoy politiki predpriiatiia [Methodological Support for Corporate Career Policy]. In Menedzhment v Rossii i za rubezhom [Management in Russia and Abroad], 3, 108-114.

Bersin, J. (2015) Why People Management is Replacing Talent Management. Available at: http:/joshbersin.com (accessed 23.11.2018).

Eriomina, I.Y., Toderash, V.A. (2016). Upravlenie kar'eroi v Rossii i za rubezhom [Career Management in Russia and Abroad]. In. Problemy ekonomiki i upravleniia neftegazovym kompleksom [Problems of Economy and Management of Oil and Gas Complex], 2, 12-15.

Hassell, B. (2017). At Vi, Business is All About Living and Learning. In Chief Learning Officer, 16(5), 32-33, Available at: https://issuu.com/chief-learning-officer/docs/co0617 issuu (accessed 20.11.2018).

Hall, D.T., Mirvis, P.H. (1995). The New Career Contract Developing the Whole Person at Midlife and Beyond». In Journal of Vocational Behaviour, 35, 64-75.

London, M., Moon, E.M. (1987). Career Management and Survival in the Workplace. Jossey-Bass, San Francisco, CA.

Masie, E. (2017). The Future of Learning Careers. Shrinking Learning Departments Reflect a Changing Role for Learning. In Chief Learning Officer, 16 (7), 10, Available at: http://www.clomedia.com/2017/08/17/ future-learning-careers (accessed 26.11.2018).

Miliaeva, L.G. (2016). Diagnostika razvitiia professional'noy kar'ery personala v usloviiakh realizatsii kompetentnostnogo podkhoda [Diagnostics of Professional Career Development in the Context of Competence-Based Approach]. In Upravlenie chelovecheskim potentsialom [Human Potential Management], 1, 52-58.

Savickas, M.L. (1992). New Directions in Career Assessment, D.H. Montross \& C.J. Shinkman (Eds.). In Career Development: Theory and practice, 336-355. Charles C. Thomas, Springfield, IL.

Noe, R.A., Noe, A.W., Bachuber, J.A. (1990) An Investigation of the Correlates of Career Motivation. In Journal of Vocational Behaviour, 3 (37), 340-356.

Schein, E. (1986). A Critical Look at Current Career Development Theory and Research. In D.T. Hall and Association (Eds.). Career development in organization. Jossey-Bass, San-Francisco, CA.

Shpektorenko, I.V. (2013). Sotsial'nye lifty v strukture sotsial'noy mobil'nosti individa [Social Lifts in the Structure of Social Mobility of the Individual]. In Upravlencheskoe konsul'tirovanie [Management consulting], 6 (54), 93-103.

Sillaste, G.G. (2004). Gendernaia asimmetriia kak faktor kar'ernogo rosta zhenshchin [Gender Asymmetry as a Factor of Women's Career Growth]. In Vysshee obrazovanie v Rossii [Higher education in Russia], 3, 122-133.

Sotnikov, N.Z. (2015). Delovaia kar'era kak metamodel' upravleniia konkurentosposobnost'iu naemnogo personala [Business Career as Hired Personnel Competiveness Management Metamodel]. In Vestnik NGUEU [Vestnik NSUEM], 1, 190-200.

Sotnikova, S.I. (2018). Novyy kontur otsenki konkurentosposobnosti nauchno-pedagogicheskikh rabotnikov: nezavisimaia otsenka kvalifikatsii [New Contour of Assessment of the Research and Teaching Personnel Competitiveness: Independent Qualification Assessment]. In Universitetskoe upravlenie: praktika i analiz [University Management: Practice and Analysis], 22(3), 113-126. 


\title{
Деловая карьера в российских банковских организациях: приоритеты и возможности
}

\author{
Н.3. Сотников, С.И. Сотникова, \\ Е.М. Михайлова \\ Новосибирский государственный университет \\ экономики и управления \\ Российская Федеращия, Новосибирск
}

\begin{abstract}
Аннотация. В условиях высокой неопределенности и динамичности российской окружающей социально-экономической среды, становления «прозрачного» мирового рынка такие традиционные методы повышения эффективности труда, как рационализация и автоматизация бизнес-процессов, поиск талантов, зачастую не приводят к повышению конкурентоспособности человеческих ресурсов. Для того чтобы быть конкурентным, необходимо создание условий для постоянного стремления работника к осознанному формированию долгосрочного превосходства над работниками-конкурентами, преумножения конкурентных компетенций каждого посредством деловой карьеры. В этом контексте возрастает необходимость познания общего характера и глубинных причин процессов организации, развития и разрушения деловой карьеры, возможности трансформации ее стратегий с учетом конкурентной позиции банковской организации. Цель исследования состоит в выявлении организационно-экономических закономерностей деловой карьеры, обусловленных различиями в конкурентной позиции банковских организаций: (а) выявить детерминанты деловой карьеры, позволяющие достичь более высокого уровня в конкуренции на рынке труда в изменяющихся условиях; (б) проанализировать возможные стратегические альтернативы деловой карьеры путем построения двухмерных матриц, позволяющих оценить перспективы того или иного способа позиционирования банковского персонала на рынке труда. По содержанию происходит анализ деловой карьеры персонала 15 федеральных и региональных банков, котирующихся на российском рынке в течение шести лет. Результаты показывают, что вид и интенсивность деловой карьеры определяют механизмы локализации и утверждения конкурентного превосходства как работника, так и банковской организации в рыночной ситуации. Познание деловой карьеры позволило выявить наличие социально-экономического конфликта между профессиональной карьерой и организационной (внутри- и межорганизационной). Способы разрешения конфликта деловой карьеры формируют стратегические альтернативы взаимодействия профессионального и организационного видов карьеры, направленные на поддержание и повышение конкурентоспособности человеческих ресурсов банковской организации.
\end{abstract}

Ключевые слова: коммерческий банк, конкурентоспособность персонала, деловая карьера.

Научная специальность: 08.00.00 - экономические науки. 